\title{
Anthropogenic impacts on the Glowworm Cave, Waitomo, New Zealand: a microclimate management approach
}

\author{
Chris H. Hendy (10) ${ }^{1}$, David J. Merritt (102 ${ }^{2 *}$, and Shannon Corkill (10 ${ }^{3}$ \\ ${ }^{1}$ University of Waikato, Hamilton, New Zealand \\ ${ }^{2}$ School of Biological Sciences, The University of Queensland, Brisbane, 4072, Australia \\ ${ }^{3}$ Discover Waitomo, Tourism Holdings Limited, Waitomo, New Zealand
}

\begin{abstract}
Waitomo Glowworm Cave is a highly visited cave where the highlight is viewing the bioluminescence display of a large colony of glowworms. The visitation levels result in the build-up of anthropogenic $\mathrm{CO}_{2}$, to the extent that it could cause corrosion of speleothems. The cave experiences chimney-effect ventilation with air flowing either upward or downward through the main cave chambers depending on air density differences between the cave and the outside environment. Lack of airflow leads to $\mathrm{CO}_{2}$ build-up; however, unrestricted airflow can draw in cool, dry air which is harmful to the glowworms. Consequently, airflow is managed by controlling the opening and closing of a door that seals the upper-most entrance, preventing ventilation under drying conditions and promoting ventilation when it is necessary to clear $\mathrm{CO}_{2}$ and when inflowing air has high relative humidity. A network of microclimate sensors in the cave allows prediction and management of the ventilation pattern. Management leads to asymmetric airflow through the year, which has a flow-on effect on cave temperature. Microclimate monitoring supports the current management practices that use door control to enhance cave ventilation when people are in the cave. Suppressing airflow, especially in winter, reduces the introduction of dry air.
\end{abstract}

Keywords: $\quad$ Cave microclimate, chimney effect, carbon dioxide, ventilation, automated door control, show cave Received 13 December 2021; Revised 15 February 2022; Accepted 19 February 2022

Citation: Hendy, C.H., Merritt, D.J., Corkill, S., 2022. Anthropogenic impacts on the Glowworm Cave, Waitomo, New Zealand: a microclimate management approach. International Journal of Speleology, 51(1), 59-68. https://doi.org/10.5038/1827-806X.51.1.2411

\section{INTRODUCTION}

The microclimate is a key component of a cave environment, impacting on the cave biota as well as the geological formations. In show caves, visitors introduce light and generate heat, carbon dioxide and dust, all of which can influence the cave environment. The main challenge for cave management is reducing the negative impacts of visitors to ensure sustainable use of the cave as an outstanding natural environment. Cave management can become more complex when the biota is a part of the visitor experience. In most show caves of the world, visitors come to see the cave morphology and formations: in some, visitors also come to see wildlife. An example is the cave fauna in Gunung Mulu National Park, Malaysia where visitors see cave-swifts, snakes, vast bat populations and guano inhabitants (Moulds et al., 2013). In New Zealand and Australia, visitors come to see colonies of glowworms in caves (Hall, 2013). Glowworms are bioluminescent fungus gnat larvae that can reach very high numbers in caves due to the consistent, predictable environment with high humidity, low temperature range and a predictable influx of prey items through an inflowing stream. Their light attracts the adult stages of aquatic insects that emerge from the stream and become trapped in the larval snares (Broadley \& Stringer, 2001). They are restricted to New Zealand and Australia (Baker \& Merritt, 2003; MeyerRochow, 2007). As well as caves, larvae are also found in suitably sheltered, wet forest habitats. They are very susceptible to desiccating conditions (Pugsley, 1984; Merritt \& Patterson, 2017): the silk fishing lines must be hydrated to retain length, elasticity and adhesion capability, and the hygroscopic mucus drops on the lines are used for body water homeostasis (Walker et al., 2015; von Byern et al., 2016, 2019; Piorkowski et al., 2018).

The Waitomo GlowWorm Cave (Fig. 1) in New Zealand is by far the most popular cave for viewing glowworms. An upper artificial entrance was created in 1888 by excavating through flow stone. People normally enter the cave through this entrance, following a passage and descending to the "Cathedral" chamber via stairs, 
then descending further to the "Glowworm Grotto" where they board a boat and are floated on the broad, slow Waitomo Stream toward the stream influx, along the way viewing the spectacular display of glowworms (Arachnocampa luminosa) on the cave walls and ceiling.

As visitor numbers increased in the 1970s, the potential harm to speleothems through $\mathrm{CO}_{2}$ exhalations creating condensation corrosion was recognised (Kermode, 1979). High $\mathrm{pCO}_{2}$ levels lead to corrosion of wet speleothems and condensation corrosion due to acidification of a layer of condensed water on other cave surfaces through diffusion of $\mathrm{CO}_{2}$ from the cave atmosphere (Hendy, 1971, de Freitas \& Littlejohn, 1987; White et al., 2021). Kermode (1979) argued that the $\mathrm{pCO}_{2}$ of the Waitomo cave air should be kept below 2,400 ppm to prevent speleothem degradation, and McCabe (1977) recommended that tourist numbers should be curtailed when $p \mathrm{CO}_{2}$ is 2,500 - 3,000 ppm.

Knowing that a chimney effect dominates the airflow characteristics of the Glowworm Cave (Kermode, 1977), an attempt at managing carbon dioxide levels by enhancing airflow led to the replacement of a solid door at the artificial upper cave entrance with a metal grill in 1975 (Williams, 1981; Pugsley, 1984). This allowed unrestrained airflow within the cave: warm outside air cooled and descended through the cave during summer, and cool air rose through the cave during winter (de Freitas et al., 1982; de Freitas \& Banbury, 1999). It had the unintended effect of leading to a population collapse of the glowworm colony for which the cave was famed, later established to be due to winter air warming and rising through the cave (de Freitas, 1997), reducing the relative humidity and desiccating and stressing the vulnerable larvae (Pugsley, 1984). The numbers of larvae were substantially reduced until only $4 \%$ of those present were bioluminescing (Williams, 1981).

To remedy the situation, an Environmental Advisory Group (EAG) was established, a monitoring program was set up in 1994 (de Freitas, 1997) and a climate management regime established with three main aims; (1) to keep the $p \mathrm{CO}_{2}$ below $2,400 \mathrm{ppm}$, (2) to minimise the heat input into the cave and (3) to restrict the drying of cave surfaces. Similar microclimate monitoring systems are in place at a number of show caves throughout the world (Novas et al., 2017; Mlakar et al., 2020). The cave climate management regime currently in place strikes a balance between allowing airflow to ventilate $\mathrm{CO}_{2}$ and limiting airflow to prevent desiccation of the glowworms (de Freitas et al., 1982; de Freitas \& Littlejohn, 1987; de Freitas, 1997; de Freitas \& Banbury, 1999; de Freitas \& Schmekal, 2003). In summer, coinciding with highest attendance, the door has been left open during both day and at night. On summer nights airflow was not expected to impact glowworm larvae because down-drafting should result in condensation within the cave chambers. On winter nights the door has been closed to limit upward airflow that would draw drying air into the Glowworm Grotto, promoting evaporation and having deleterious effects on the glowworms.
Here, we investigate the temperature profiles of different chambers of the cave and describe airflow velocity and direction in relation to season. We also detail how the monitoring data have been used to establish the current cave microclimate management procedures whose main aim is to remove anthropogenic $\mathrm{CO}_{2}$ by ventilation while minimising desiccation within the cave chambers.
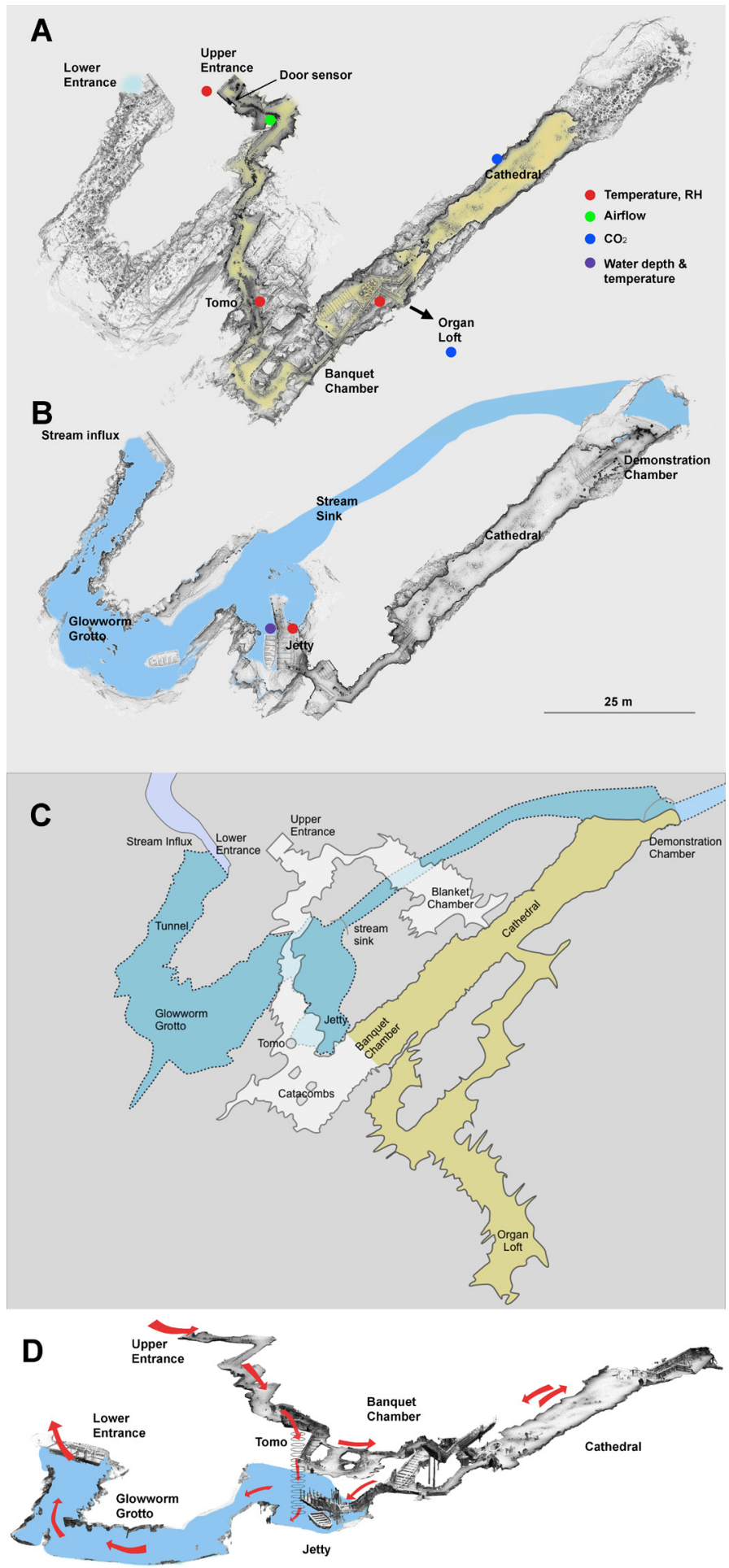

Fig. 1. Plan of Waitomo Glowworm Cave displayed showing the main pathway taken by tourists as two levels with a vertical separation of $12 \mathrm{~m}$. A. The upper level showing the main entrance. B. The lower level showing the jetty where tourists board boats and the tour exit point at the stream influx. Location of sensors is shown as coloured dots. C. A map of the main cave chambers combining data from a 3D pointcloud and from the map by De Freitas and Littlejohn (1987). D. Diagram of the main direction of airflow (arrows) under downward airflow conditions. 


\section{METHODS}

To record air temperature and relative humidity, Campbell Scientific CS107 (accuracy: $\pm 0.2^{\circ} \mathrm{C}$ over $0^{\circ}$ to $50^{\circ} \mathrm{C}$ range) sensors, configured as a psychrometer with aspirating fan, were used before 2019. They were replaced with Vaisala HMP155A temperature and relative humidity probes (accuracy: $\pm 0.055+0.0057 \mathrm{x}$ temperature $\left.{ }^{\circ} \mathrm{C}\right)$ at the Tomo and Glowworm Grotto $\left(11^{\text {th }}\right.$ of January 2019 onwards) and the Banquet Chamber (30 ${ }^{\text {th }}$ September 2019 onwards). Partial pressure of $\mathrm{CO}_{2}$ in parts per million (ppm) was monitored using Vaisala Carbocap GMP222 probes (accuracy: $\pm 1.5 \%$ of range $+2 \%$ of reading) at 2 locations, the Cathedral and the Organ Loft, the latter being recognized as a chamber that tends to accumulate $\mathrm{CO}_{2}$ (McCabe, 1977). Airflow was measured near the upper entrance using a Young 3D ultrasonic anemometer (accuracy: $\pm 2 \%$ at $12 \mathrm{~m} / \mathrm{s}$, resolution: $0.01 \mathrm{~m} / \mathrm{s}$ ). Water temperature and level ( $\mathrm{m}$ above a reference point) of the Waitomo Stream was monitored using a Campbell Scientific CS451 Submersible Pressure Transducer (temperature accuracy: $\pm 0.2^{\circ} \mathrm{C}$, pressure/level accuracy: $\pm 0.1 \%$ full scale range) located at the boat jetty in the Glowworm Grotto. All sensor locations are shown in Figure 1. Two dataloggers were deployed: the main logger (Campbell Scientific CR1000) and a second (Campbell Scientific CR10X) recording data from different subsections of the cave. Tumutumu weather station located $1.5 \mathrm{~km}$ from the cave recorded temperature, relative humidity and rainfall (tipping bucket).

Temperature and humidity were logged at $30 \mathrm{~min}$ intervals. Carbon dioxide (ppm) and river level were logged at $10 \mathrm{~min}$ intervals. Door position (minutes open over the preceding $10 \mathrm{~min}$ ), and airflow (mean wind speed in $\mathrm{m} / \mathrm{s}$ over the preceding $10 \mathrm{~min}$ ) were also logged at $10 \mathrm{~min}$ intervals. To match with the temperature readings, every third data-point of $\mathrm{CO}_{2}$, river level, door open and air-flow was used for analysis (Figs 5-7).

The plan of the cave was derived from a point-cloud dataset obtained with a Zeb Revo 3D laser point-cloud scanner, manipulated using CloudCompare and finalised using Adobe Photoshop and Sketch.

\section{RESULTS}

\section{Annual temperature cycle}

Mean annual temperatures in years $1998-2020$ are compared in Table 1 and time series of temperatures through 2019 and 2020 are compared in Figures 2 and 3 . The Tomo has the warmest mean annual temperature (Table 1). The relative temperatures of the three chambers show the same order in all years. All three monitored cave chambers in WGC show a damped annual temperature cycle compared to outside the cave (Fig. 2). In addition, the day-to-day temperature variation in all chambers is much less than that outside the cave. Of the three chambers, the Glowworm Grotto air temperature varies most through the year; the daily mean varied between 12 and $17^{\circ} \mathrm{C}$ in 2020 (Fig. 2A). The Banquet Chamber and the Tomo show less seasonal range and both sites are warmer than the Grotto through the cooler months of the year (Fig. 2). At all three sites, the temperature profiles for 2019 and 2020 are similar (Fig. 2B, D, Table 1).

Table 1. Average air temperatures determined from 30-minute observations through the year at Waitomo Glowworm Cave from 1998-2010. All temperatures in ${ }^{\circ} \mathrm{C}$. Note temperature data from the Tomo from 1st January 2019 to 20th February 2019 were missing and incomplete data precluded calculation of averages in some years at some locations.

\begin{tabular}{|l|c|c|c|c|c|c|}
\hline Year & Outside & Tomo & Banquet & Grotto & Tumutumu & Stream \\
\hline $\mathbf{2 0 2 0}$ & 12.87 & 15.40 & 14.99 & 13.81 & 13.70 & 13.32 \\
\hline $\mathbf{2 0 1 9}$ & 13.15 & 15.73 & 14.75 & 14.08 & 13.91 & 13.52 \\
\hline $\mathbf{2 0 1 8}$ & 13.07 & 15.87 & 14.67 & 14.15 & 13.78 & 13.62 \\
\hline $\mathbf{2 0 1 7}$ & 12.81 & 15.43 & 14.34 & & & 13.54 \\
\hline $\mathbf{2 0 1 6}$ & 13.41 & 15.62 & 14.59 & 14.35 & & \\
\hline $\mathbf{2 0 1 5}$ & 12.40 & 14.98 & 14.22 & 13.58 & 13.14 & \\
\hline $\mathbf{2 0 1 4}$ & 12.57 & 14.95 & 14.33 & 13.54 & 13.17 & \\
\hline $\mathbf{2 0 1 3}$ & 12.11 & 14.84 & 14.12 & 13.62 & 13.36 & \\
\hline $\mathbf{2 0 1 2}$ & 12.06 & 14.85 & 14.09 & 13.46 & 13.03 & \\
\hline $\mathbf{2 0 1 1}$ & 12.70 & 15.16 & 14.31 & 13.86 & & \\
\hline $\mathbf{2 0 1 0}$ & 12.74 & 14.66 & 14.22 & 13.91 & & \\
\hline $\mathbf{2 0 0 9}$ & 11.72 & 14.97 & 14.01 & 13.56 & & \\
\hline $\mathbf{2 0 0 8}$ & 12.81 & 14.96 & 14.31 & 14.23 & & \\
\hline $\mathbf{2 0 0 7}$ & 12.64 & 14.70 & 13.68 & 13.21 & & \\
\hline $\mathbf{2 0 0 5}$ & 14.40 & 14.87 & 14.42 & 14.11 & & \\
\hline $\mathbf{2 0 0 4}$ & 12.19 & 14.61 & 13.74 & 12.47 & & \\
\hline $\mathbf{2 0 0 3}$ & 13.34 & 16.03 & 14.54 & 13.89 & & \\
\hline $\mathbf{2 0 0 2}$ & 14.08 & 16.68 & 14.46 & 14.02 & & \\
\hline $\mathbf{2 0 0 1}$ & 13.54 & 16.80 & 15.22 & 14.23 & & \\
\hline $\mathbf{2 0 0 0}$ & 13.49 & 16.41 & 15.36 & 14.73 & & \\
\hline $\mathbf{1 9 9 9}$ & 13.89 & 16.89 & 15.80 & 15.31 & & \\
\hline $\mathbf{1 9 9 8}$ & 13.94 & 16.52 & 15.66 & 15.14 & & \\
\hline
\end{tabular}



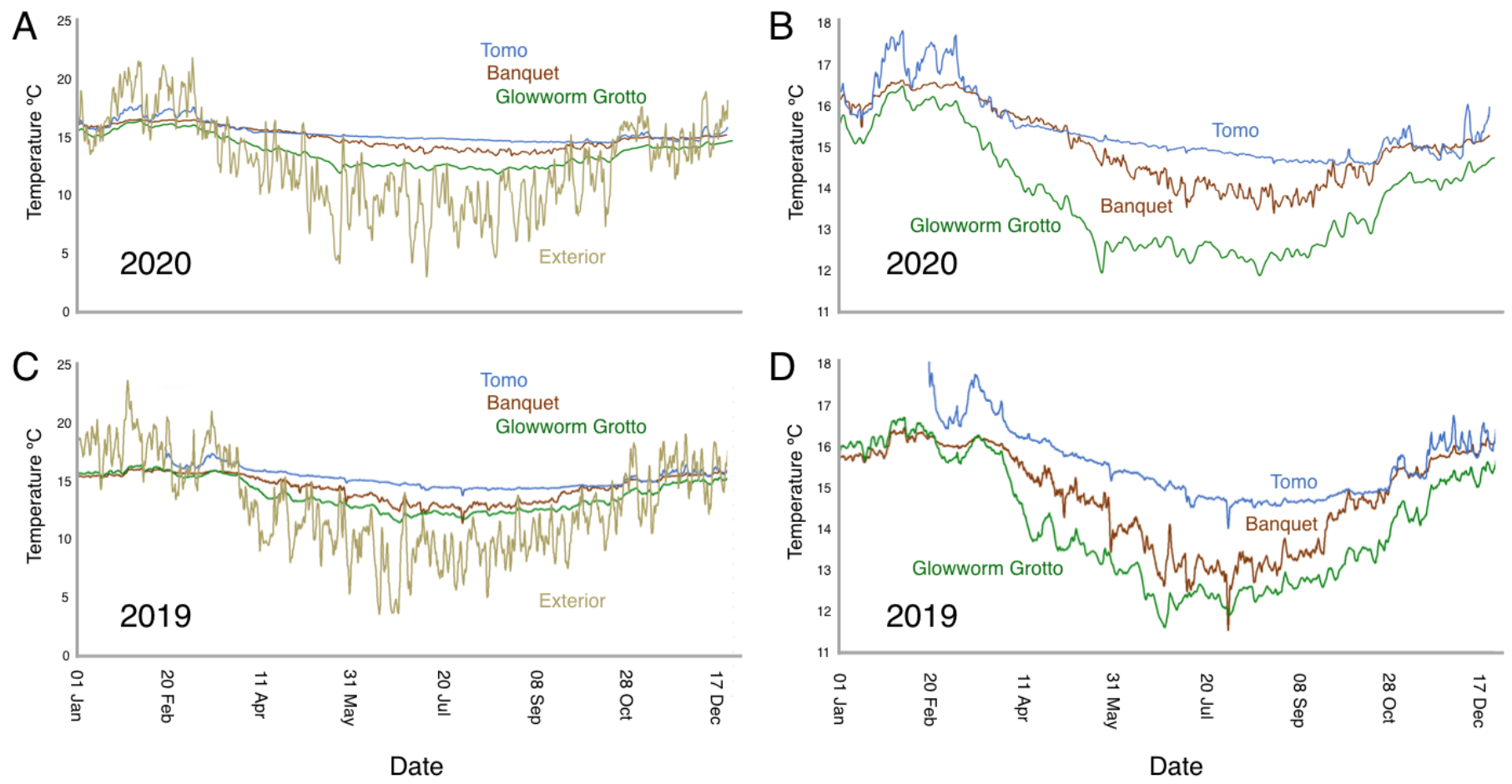

Fig. 2. Temperature in Waitomo Glowworm Cave in 2019 and 2020. A. Daily mean temperature (moving average over $24 \mathrm{~h}$ of $30 \mathrm{~min}$ interval readings to remove daily cycles) through 2020 at three locations inside the cave and one outside near the upper entrance. B. The same data as $A$ with the exterior sensor data removed and the temperature scale expanded to illustrate differences between chambers. $\mathbf{C}$ and $\mathbf{D}$. The same depiction as A and B for the year 2019. Note that the temperature data for the Tomo site are missing from early 2019.

At the Glowworm Grotto and Tomo, the daily variation, i.e., the amplitude of the daily cycles shown in the inset of Figure 3B, is greatest in summer and reduces through winter (Fig 3B, D); whereas, the Banquet Chamber shows most variation in the daily amplitude cycle throughout the year (Fig. 3F).
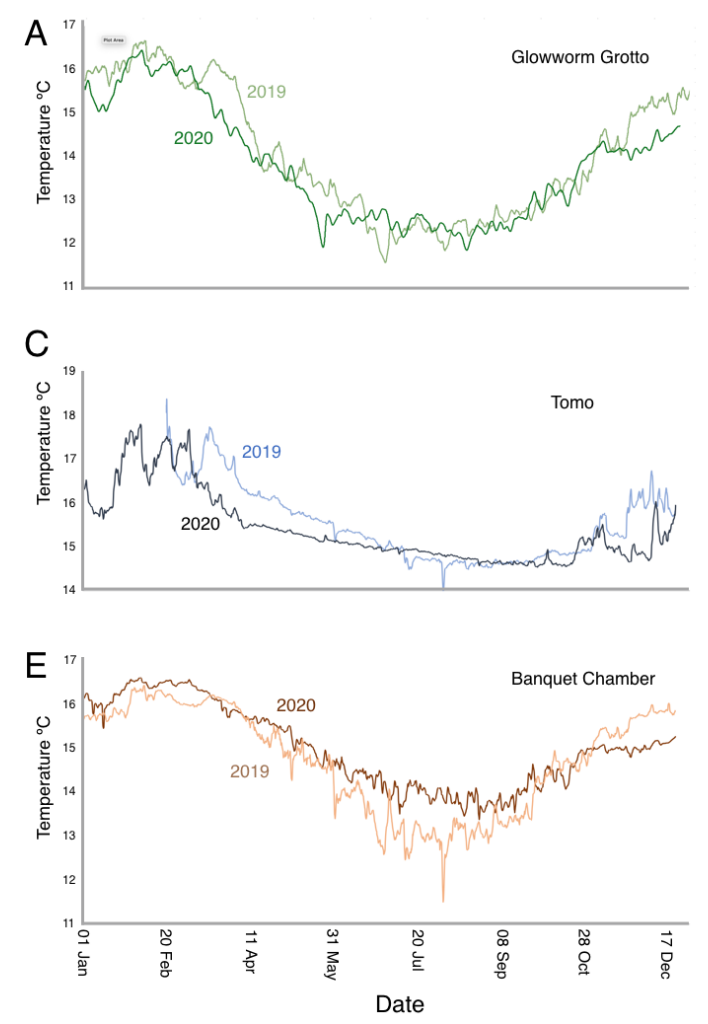

The Glowworm Grotto is contiguous with the stream influx opening, which represents the lowest level of the cave and the lowest point in the Waitomo Valley prior to the ridge through which the cave passes. The opening is not sealed to airflow, explaining why it shows the lowest temperatures and highest annual range of the three chambers.
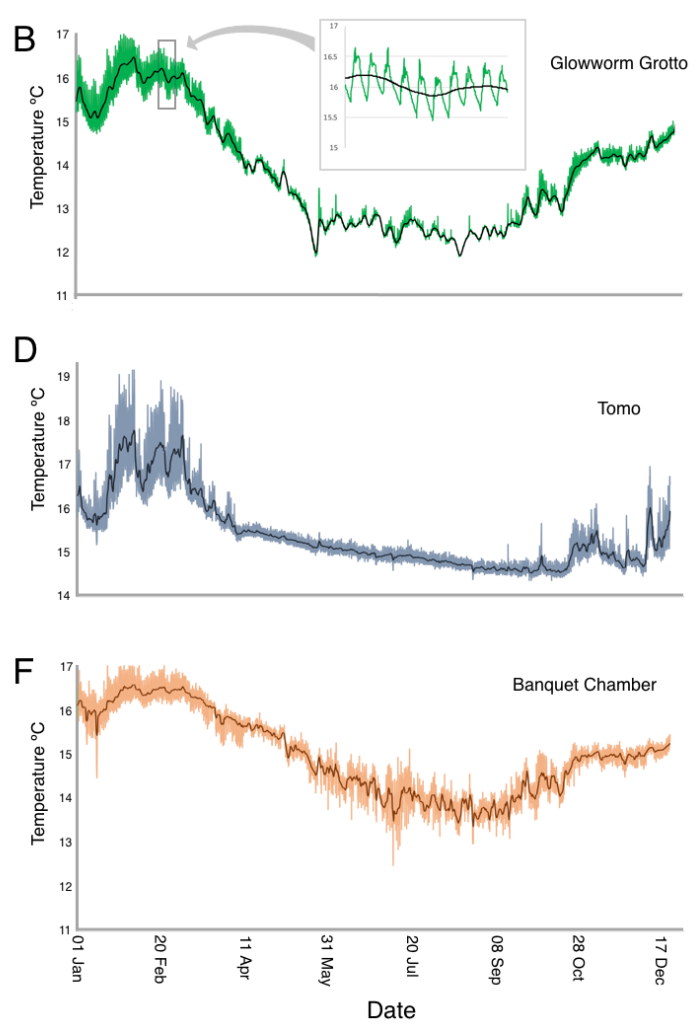

Fig. 3. Temperature in Waitomo Glowworm Cave chambers. A, C, E. Temperature at different sensor locations comparing years 2019 and 2020 (30 min interval readings). A. Glowworm Grotto. C. Tomo. E. Banquet Chamber. B, D, F. Thirty-minute interval data points shown along with the moving average for 2020 to illustrate daily variation. In B the inset shows a 10 -day subset of the time series showing the nature of daily cycles. 


\section{Density-dependent airflow}

Air circulation through Glowworm Cave is driven by density differences mainly resulting from thermal gradients between cave temperature and outside air temperature (de Freitas \& Littlejohn, 1987), a common seasonally-driven feature of cave microclimate (Badino, 2010; Covington \& Perne, 2015; Kukuljan et al., 2021b). When the external temperature is greater than the internal temperature (a positive gradient), density differences lead to downdrafting and vice versa, air flows upward when the gradient is reversed (negative gradient) (Fig. 4A, B).

Examining annual cycles, in year 2019, the external temperature stayed above cave temperature on warm summer days resulting in only downflow on 11 days of 2019. On cold winter days ( $n=156$ days), it stayed below cave temperature, resulting in upflow only. On the remaining days ( $\mathrm{n}=198$ days) the temperature gradient and the airflow direction transitioned during the day (Fig. 4C). The net airflow for each day of 2019 shows downflow predominating in summer and upflow in winter (Fig. 4D).
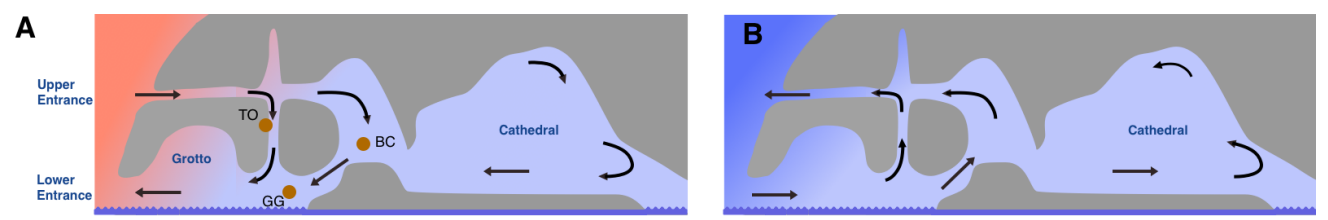

C

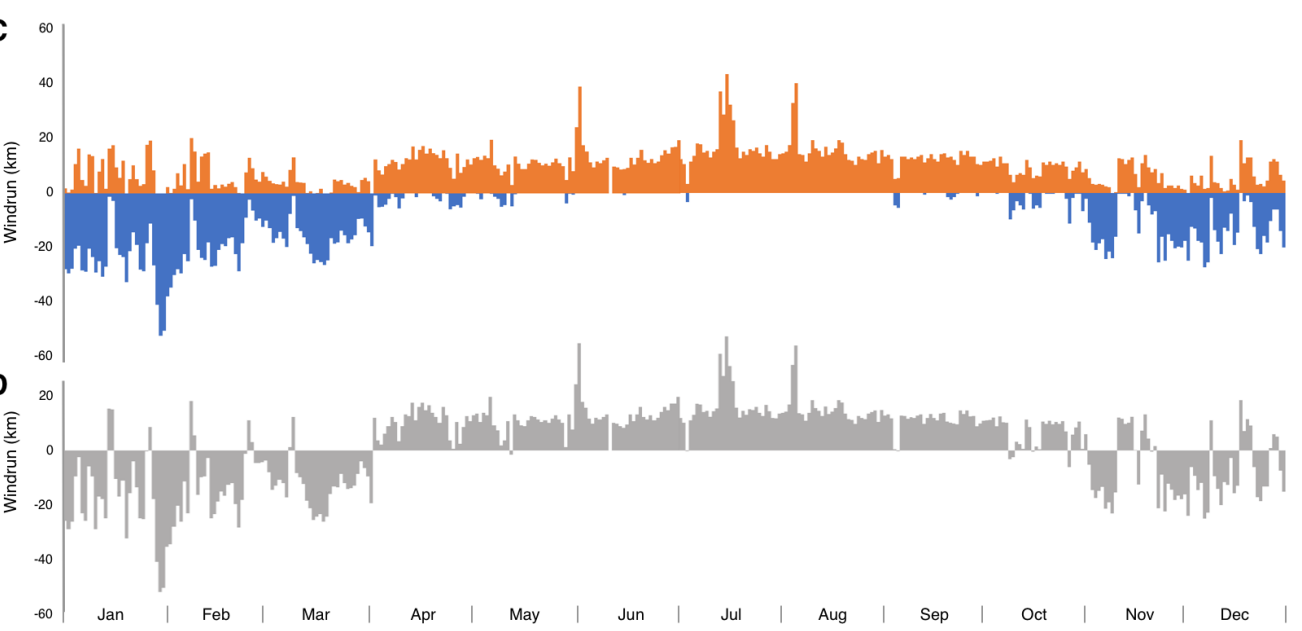

Fig. 4. A schematic representation of air flow through Glowworm Cave (after de Freitas and LittleJohn 1987) under summer conditions (A) and winter conditions (B). Note that in reality the upper and lower entrances are on opposite sides of the ridge. Letters depict approximate location of sensors: $\mathrm{TO}=$ Tomo, $\mathrm{BC}=$ banquet Chamber, $\mathrm{GG}=$ Glowworm Grotto. C. The direction of airflow each day for 2019. Windspeed and direction were assessed at $30 \mathrm{~min}$ intervals and converted to windrun per day. Downward flow is blue and upward flow is orange. D. The net windrun for each day of 2019.

The degree of airflow was managed during this period by opening or closing the upper-level door according to criteria listed in Supplementary Table S1 and S2. When the door is open, the airflow velocity is dependent on air density differential; however, the relationship is not linear (Fig. 5), and is similar to airflow characteristics seen in other chimney-effect caves, scaling with the square root of the air density differential (Covington et al., 2021). Closing the door suppresses the chimneyeffect airflow but does not completely prevent it (Fig. 5A), likely due to percolation of air through fine passages or crevices accessing the exterior.

While temperature differential is a useful proxy for airflow velocity and direction, the density differentialwhich incorporates the influence of relative humidityis a more precise predictor (Fig. 5B). The internal cave air maintains relative humidity close to $100 \%$, while the outside air varies considerably, tending to be lower when temperatures are at their maxima and higher at the minima. Low relative humidity in outside air makes it denser than cave air at the same temperature, enhancing downflow during the summer months. During winter months when outside temperatures are colder than cave temperatures, both inside and outside air have relative humidities near $100 \%$. When the denser outside air enters at the bottom of the cave it begins to warm, but in doing so the relative humidity drops, keeping its density lower than cave air of the same temperature, thus impeding the onset of up-drafting. Despite previous authors identifying the Tomo site temperatures as critical for driving the "chimney effect" (de Freitas et al., 1982), if the temperature is combined with relative humidity to estimate the potential air density (The Engineering Toolbox, 2001), the best predictor of airflow through the cave is obtained using data from the Banquet Chamber site (Fig. 5).

Heat exchange between air flowing through the cave and the cave walls is demonstrated by the progressive rise in temperature in the vertical Tomo passage during down-drafting and lowering in temperature during up-drafting (Fig. 6A). Daily elevation of the external temperature above the Tomo temperature resulted in increased air flow and, at the end of the diurnal cycle, a small increase in the Tomo temperature (Fig. 6). Contiguous records for five typical days when the door was open are displayed in Fig. 6A. In general, up-drafting occurs on winter days, and on summer days either down-drafting occurs or the gradient transitions during the day, inducing bi-directional airflow on days when the temperature relationship crosses the temperature identity line (Fig. 6B). 
A
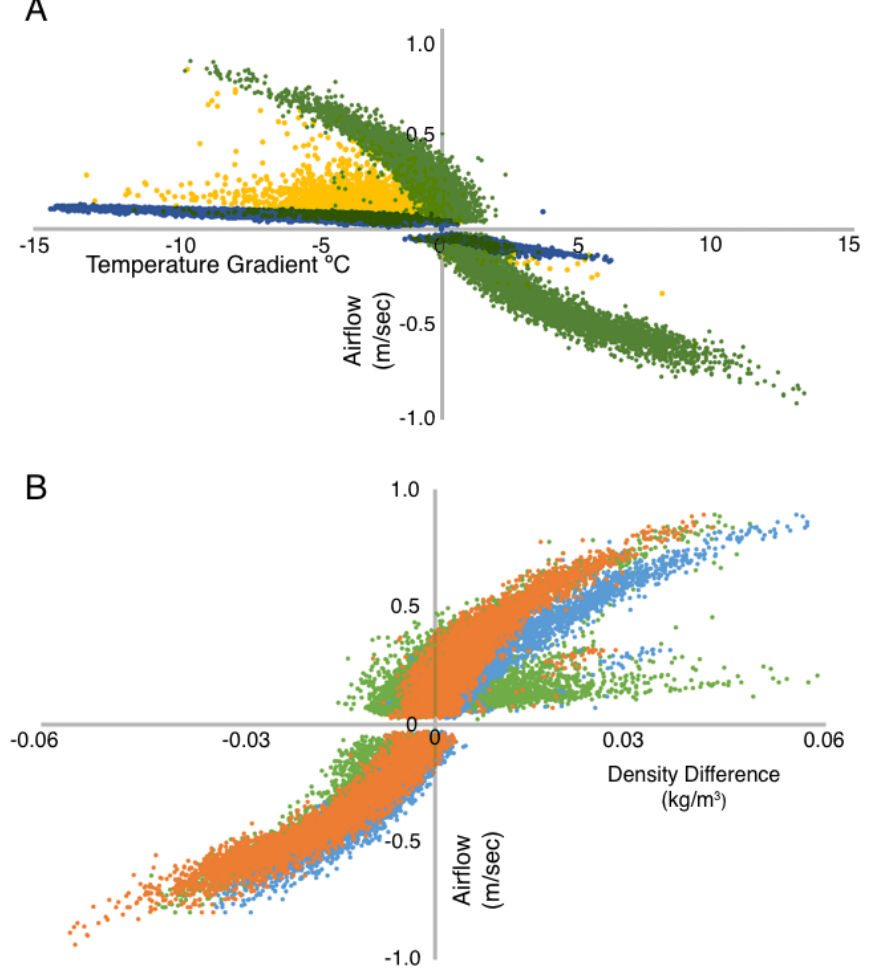

Fig. 5. Airflow in relation to $(\mathbf{A})$ temperature gradient ( $T^{\text {grad }}=T^{\text {out }}-T^{\text {Banq: }}$ the difference between external temperature taken at a sensor located outside the upper cave entrance and the Banquet Chamber) and (B) air density gradient. Upflow is positive and downflow negative. The data points were taken at 30 minute intervals from 1 Jan 2019 to 31 Dec 2019. A. The green points represent air-flow in relation to temperature gradient when the door was open for the preceding 10 minutes, blue points when the door was closed for the preceding 10 minutes and orange points when the door was open for part of the 10 minutes. B. The air flow velocity in relation to the differences between the densities of outside air and each of the three internal cave monitoring sites during 2019. The green points represent the Glowworm Grotto, the blue points the Tomo and the orange points the Banquet Chamber. Shows only those readings where the door remained open for the preceding 10 minutes allowing unrestricted airflow.
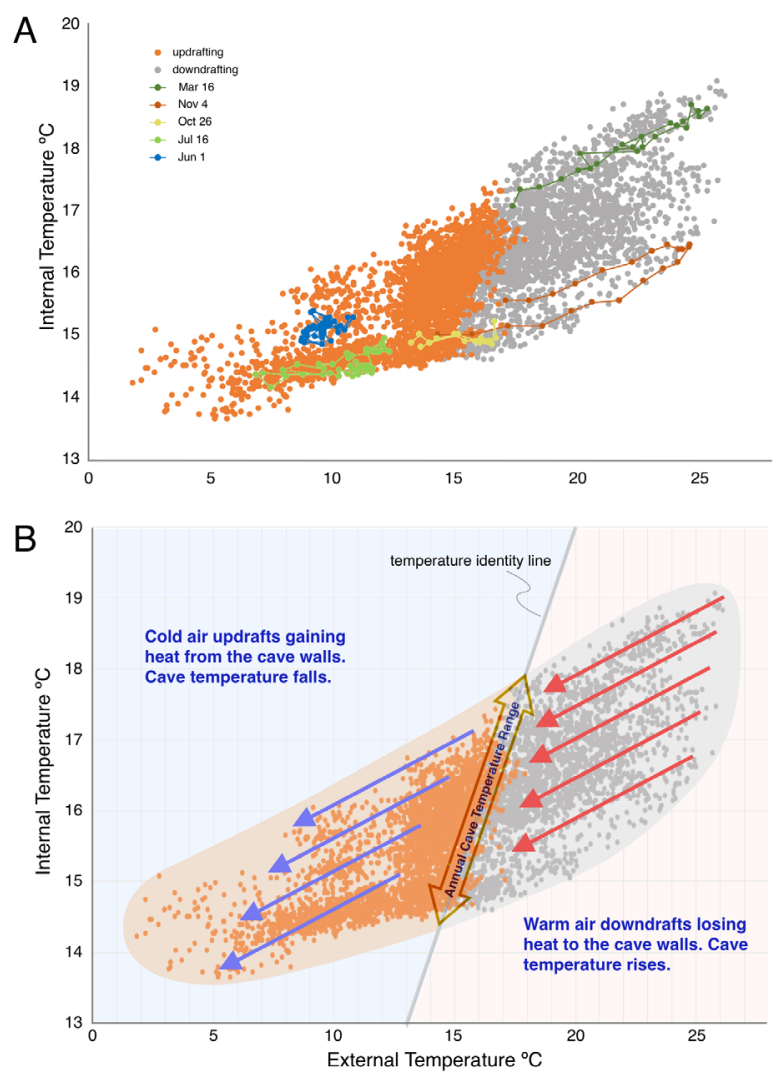

Fig. 6. A. Air temperature at the Tomo site and the outside at 30 intervals through all of 2019 when the door at the upper entrance was open. The data are depicted according to air flow direction, with down-drafting in grey and up-drafting in orange. Contiguous 30 minute observations are shown for two down-drafting days (16 Mar and 4 Nov), two up-drafting days (1 Jun and 16 July) and one day when airflow transitioned between up- and down-flow (26 Oct). Note that door management attempts to limit the extent of up-drafting whilst allowing down-drafting. B. Diagrammatic representation of the influence of external temperature on airflow dynamics in Waitomo Glowworm Cave. 


\section{$\mathrm{CO}_{2}$ clearance by airflow}

To illustrate the relationship between air temperature, $p \mathrm{CO}_{2}$ and airflow, climate over 8 days of December 2019 is shown as a time-series in Figure 7. During the period, the upper entrance door was used to control airflow based on management policies detailed in Supplementary Table S1. The air density differential, illustrated here by the temperature gradient ( $\left.T^{\text {grad }}\right)$, was generally positive but the high summer daily range in external temperature resulted in $\mathrm{T}^{\mathrm{grad}}$ transitions every day, producing changes in airflow directional propensity within a day. During daylight hours, when the door is generally left open (blue bars in Fig. 7), downward airflow predominates. Through the nights, the airflow propensity is upwards but its velocity is curtailed by the door being closed (white bars in Fig. 7 ), restricting airflow to $<0.1 \mathrm{~m} / \mathrm{s}$. When open, flow velocity at the sensor site can approach $1 \mathrm{~m} / \mathrm{s}$.
The $\mathrm{CCO}_{2}$ rises rapidly each day as visitors enter the cave and drops at the end of the day as visits cease. The door is open during the day allowing ventilation that clears anthropogenic $\mathrm{CO}_{2}$. Day 1 in Figure 7 saw a high $p \mathrm{CO}_{2}$ level due to the fact that during the middle of the day, when visitor numbers were highest, the airflow was low because the $T^{\text {grad }}$ was low on that particular day. In the early morning of days 6 and 8, the door opened automatically due to a build-up of $\mathrm{CO}_{2}$ at a nearby sensor site. On the afternoon of day 7 , the door stayed open longer than normal because $p \mathrm{CO}_{2}$ remained high due to the lack of airflow, which in turn was due to a nearzero temperature gradient. Each day, the lowest $p \mathrm{CO}_{2}$ tends to occur after the last tours finished just before the door was closed for the night. Through the nights, the $\mathrm{pCO}_{2}$ rose slightly, indicating a possible $\mathrm{CO}_{2}$ source within the cave.
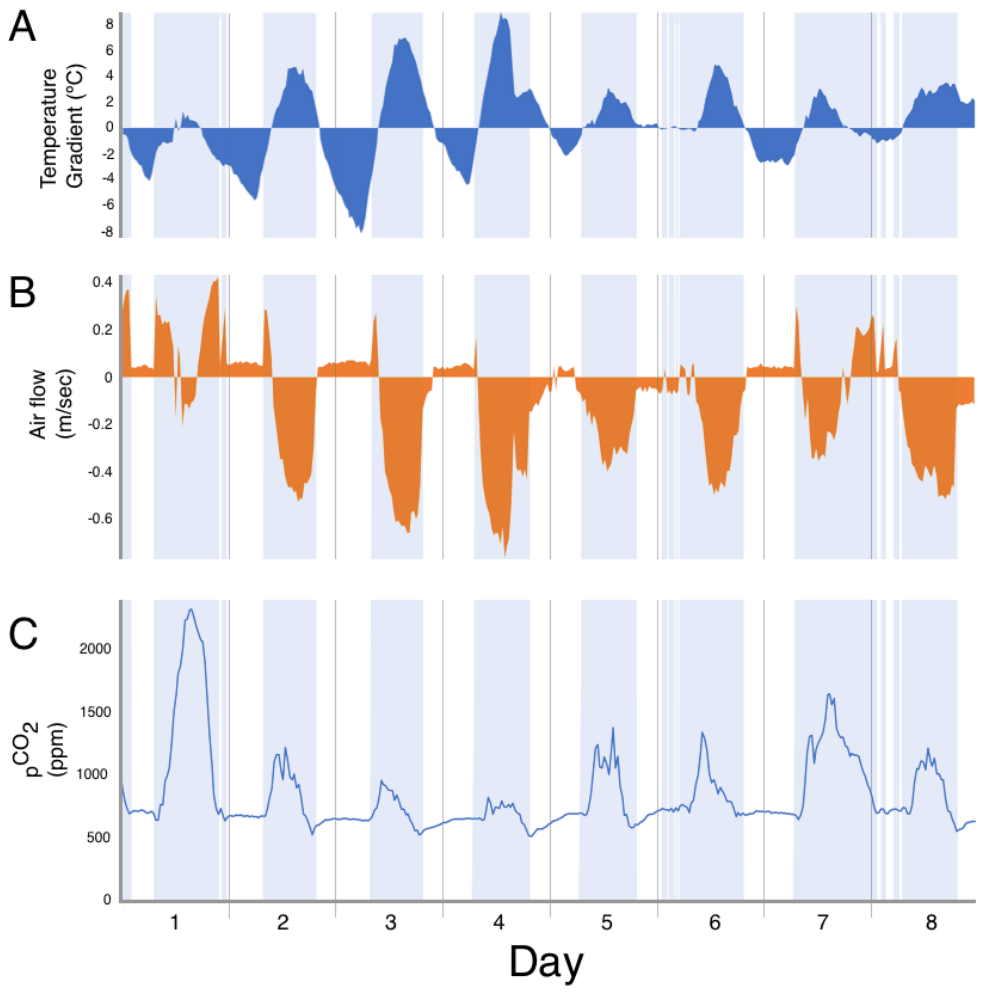

Fig. 7. Waitomo Glowworm Cave microclimate over a representative 8-day period in summer (9-16 Dec 2019). A. The differential between external temperature and internal temperature measured at the Banquet Chamber ( $\left.\mathrm{T}^{\mathrm{grad}}\right)$. B. Airflow measured near the upper entrance (downflow is negative). C. $\mathrm{pCO}_{2}$ measured at the Cathedral Chamber. The blue background bars indicate times when the door is open. The grey vertical bars represent midnight.

\section{DISCUSSION}

\section{Temperature cycles}

Temperatures within a cave are influenced by a number of factors including the temperature of the surrounding rock, the extent to which water and air flowing through the cave can exchange heat, heat produced by people, heat produced by supporting infrastructure within the cave, latent heat released or absorbed when water evaporates or condenses within the cave, and work done through adiabatic compression or expansion of air moving through the cave.

The seasonal variation in outside air temperatures of about $15^{\circ} \mathrm{C}$ resulted in seasonal ranges of about $4^{\circ} \mathrm{C}$ at the Glowworm Grotto, and about $3^{\circ} \mathrm{C}$ at the Banquet and Tomo sites. There were also differences in the average annual temperatures between the sites (Table 1), with a pattern of increasing temperature from stream entrance at the Glowworm Grotto to the Banquet Chamber to the Tomo.

These temperature differences can be related to the cave ventilation strategy, which has an asymmetric impact on heat flow into the cave, with warming downflow dominating cooling up-flow 156 days to 11 days during 2019 (Fig. 4). Flow occurred in both directions on the remaining days. As a consequence, the cave temperature approaches the external temperature in summer when downflow is promoted and sits above the external temperature in winter when upflow is inhibited. Lower chambers of the cave (Grotto and Banquet sites) had both lower mean temperatures (Table 1) (less heat available for exchange from down 
drafting) and greater variability, especially when cold air pooling at the bottom of the Waitomo Valley system penetrates through the open stream entrance (Fig. 3A, E). Conversely, the Tomo site experiences less temperature variability during the winter months when up-drafting is suppressed than in the summer months when down-drafting is enhanced (Fig. 3C). The same trend for air temperature range to decrease with distance into the cave was noted in an earlier study by de Freitas and Littlejohn (1987) carried out in 19791980 , before the sealed upper door was installed and when chimney-effect airflow was unchecked. The minimum temperatures for the Glowworm Grotto recorded in that study were much lower than those reported here because door management now prevents upflow under cold external temperatures.

Airflow in relation to cave temperature is summarised in Figure 6B. It is apparent that when external temperatures are high, the cave is warmed and when external temperatures are low, the cave is cooled, the cycle repeating annually. Despite the asymmetric nature of the airflow through the cave, examination of temperature records since 1998 (Table 1) shows no substantial changes in cave temperatures compared to the outside air temperatures over that period so the cave is not being progressively warmed through airflow management.

In Postojna cave, Slovenia, which has comparable visitor numbers to Waitomo Glowworm Cave, air and rimstone pool water temperatures were found to rise in association with major visitation events but the increases were small compared to temperature changes attributable to airflow (Šebela \& Turk, 2014), similar to what we describe here in Waitomo Glowworm Cave.

Temperature variation per se does not detrimentally affect the larvae: they are present in large numbers at sites along the Waitomo Stream outside the cave (Richards, 1960) where they experience daily temperature variation far exceeding that in the Glowworm Grotto. There are behavioural differences between glowworm populations inside and outside the cave including different rates of prey capture between habitats and a day-time, dormant, non-glowing period in external populations (Broadley \& Stringer, 2009). As noted by Pugsley (1984), air currents cause tangling of the glowworm silk lines which itself can be detrimental. It is known that larvae produce longer lines in situations where there is less air flow (Richards, 1960) and they expend time, energy and water disentangling and secreting new lines when repeatedly exposed to air currents (Willis et al., 2010; von Byern et al., 2016). Consequently, it is likely that reduction of airflow within the Glowworm Grotto is beneficial to larvae, and is a separate issue to the drying power of the air.

\section{Door status as a climate management tool}

The Waitomo Glowworm Cave is small in comparison to many of the world's show caves with similarly high visitation levels; consequently, anthropogenic $\mathrm{CO}_{2}$ accumulation can be problematic due to potential condensation corrosion of speleothems. A series of microclimate studies under the supervision of the late Chris de Freitas resulted in the current management approach that monitors environmental parameters and uses door control to facilitate or restrict ventilation, and minimise impacts of the airflow on the glowworm population (de Freitas et al., 1982; de Freitas \& Littlejohn, 1987; de Freitas, 1997, 2010; de Freitas \& Banbury, 1999; de Freitas \& Schmekal). The relationship between airflow velocity and the temperature gradient at Waitomo Glowworm Cave is now well understood. When the door is open, airflow velocity scales with the square root of the temperature difference between outside and cave air as described in other cave systems (Covington et al., 2021). When the door is closed, airflow velocity is curtailed (Fig. 5A). The chimney ventilation (de Freitas 1997), when managed asymmetrically through the seasons results in the three monitored chambers having higher average temperatures than either the outside air or the Waitomo Stream flowing through the cave (Table 1, Fig. 2). The dynamics of air-flow in relation to the internal-external temperature gradient and upper door status now allows prediction of days when $\mathrm{pCO}_{2}$ could approach the specified threshold of $2,400 \mathrm{ppm}$. This tends to happen when the external temperature is close to the cave temperature and the consequent low airflow leads to $\mathrm{CO}_{2}$ build-up when attendance is high. In extreme cases, cave visits have been curtailed to prevent $\mathrm{pCO}_{2}$ exceeding 2,400 ppm.

Since February 2019, the door has been operated on an automated cycle to allow after-hours management of air-flow based on real-time $\mathrm{pCO}_{2}$ monitoring. After tours are finished, the door stays open to allow ventilation until $\mathrm{pCO}_{2}$ in the Cathedral chamber drops below 800 ppm as detected by a sensor in the chamber. At that point, the door automatically closes until the next day when the door is opened for the first tour at 7:00 am and the cycle repeats. The door-opening rules also take into account the outside temperature as an indicator for upward or downward airflow, as detailed in Supplementary Table S1.

High $\mathrm{pCO}_{2}$ can occur on days when the external temperature is close to the temperature of the cave chambers and, to a lesser extent, on days when the external temperature transitions across the cave temperature, usually twice per day, creating reversals between up- and down-drafting. When combined with high visitor numbers, $\mathrm{CO}_{2}$ accumulates and sometimes management action needs to be taken to limit the number of visitors.

\section{CONCLUSIONS AND MANAGEMENT IMPLICATIONS}

Waitomo Glowworm Cave is perhaps the most intensively climate-managed show cave in the world, primarily due to the need to ventilate anthropogenic $\mathrm{CO}_{2}$. Other show caves around the world monitor the microclimate but we are not aware of any that use a similar degree of intervention. At Ingleborough Show Cave in the United Kingdom, a fan is in operation whenever visitors are in the cave to prevent accumulation of radon (Smith \& Wynn, 2013). It has 
the effect of reducing the natural $\mathrm{CO}_{2}$ gradient in the cave which tends to increase with depth. Postojna Cave in Slovenia has thousands of visitors per day but they do not have the same impact on $\mathrm{CO}_{2}$ seen at Waitomo Glowworm Cave because of the large internal volume of the cave, the high degree of ventilation and the artificially enlarged main entrance. A combination of chimney effect and wind effect ventilation prevents accumulation of anthropogenic $\mathrm{CO}_{2}$ despite the large number of visitors (Prelovšek et al., 2018; Kukuljan et al., 2021a, b). The background level at time of low visitation at Postojna is estimated to be around 600 ppm in winter and spring, and in the summer around 800 ppm (Šebela et al., 2013).

We have presented details of cave climate management, the aim of which is to utilise airflow to clear $\mathrm{CO}_{2}$. The conditions under which high $\mathrm{CO}_{2}$ can reach a high threshold at which point tours are curtailed $(>2,400 \mathrm{ppm})$ have become predictable. Such high-risk days occur in summer when many visitors are present, such as school holidays or public holidays, combined with a low temperature gradient between the cave and outside. While not detailed here, the cave microclimate management regime has used a predictive model to estimate maximum $\mathrm{pCO}_{2}$ for any day, based on the expected number of visitors, the predicted temperature gradient between the interior and exterior cave temperature, the cave $\mathrm{pCO}_{2}$ at the start of the day, and the status of the door through the day. The predictive model was not needed through 2020 and 2021 because the number of visitors to the cave was severely curtailed due to covid-19 pandemic-related lockdowns in New Zealand. The lockdown conditions have created the opportunity to examine the dynamics of the cave microclimate when no visitors are present, which will be the basis of a subsequent report.

\section{ACKNOWLEDGEMENTS}

The authors thank the members of the Waitomo Glowworm Cave Environmental Advisory Group (EAG) whose discussions over the years have led to a refined understanding of the cave microclimate. In particular we thank and acknowledge the late Chris de Freitas, past chair of the EAG, whose contributions to cave microclimate research, in particular through his work at Waitomo Glowworm Cave, have been invaluable in local and international cave microclimate studies. We thank Allan Hosking of Survey Solutions Limited for providing the point-cloud dataset to create cave plan figures.

Authorship statement: SC coordinated and managed the data collection. $\mathrm{CH}$ and DM designed the approach and carried out data analysis. DM designed the figures. $\mathrm{CH}, \mathrm{DM}$, and $\mathrm{SC}$ carried out interpretation, drafting and critical revision.

\section{REFERENCES}

Badino, G., 2010. Underground meteorology - "What's the weather underground?". Acta Carsologica, 39(3), 427-448. https://doi.org/10.3986/ac.v39i3.74
Baker, C.H., Merritt, D.J., 2003. Life cycle of an Australian glow-worm Arachnocampa flava Harrison (Diptera: Keroplatidae: Arachnocampinae: Campara). Australian Entomologist, 30(2), 45-55.

https://search.informit.org/doi/10.3316/ informit.076660174171966

Broadley, R.A., Stringer, I.A.N., 2001. Prey attraction by larvae of the New Zealand glowworm, Arachnocampa luminosa (Diptera: Mycetophilidae). Invertebrate Biology, 120(2), 170-177.

https://doi.org/10.1111/j.1744-7410.2001. $\underline{\text { tb00121.x }}$

Broadley, R.A., Stringer, I.A.N., 2009. Larval behaviour of the New Zealand glowworm, Arachnocampa luminosa (Diptera: Keroplatidae), in bush and caves. In: MeyerRochow, V.B. (Ed.), Bioluminescence in focus - a collection of illuminating essays. Research Signpost, Kerala, p. 325-355.

Covington, M.D., Knierim, K.J., Young, H.A., Rodriguez, J., Gnoza, H.G., 2021. The impact of ventilation patterns on calcite dissolution rates within karst conduits. Journal of Hydrology, 593, 125824. https://doi.org/10.1016/j.jhydrol.2020.125824

Covington, M.D., Perne, M., 2015. Consider a cylindrical cave: A physicist's view of cave and karst science. Acta Carsologica, 44(3), 363-380.

https://doi.org/10.3986/ac.v44i3.1925

de Freitas, C.R., 1997. Cave monitoring and management: the Glowworm Cave, New Zealand. In: Cave and Karst Management in Australasia XII, Waitomo, New Zealand: 55-65.

de Freitas, C.R., 2010. The role and importance of cave microclimate in the sustainable use and management of show caves. Acta Carsologica, 39, 477-489.

https://doi.org/10.3986/ac.v39i3.77

de Freitas, C.R., Banbury, K., 1999. Build up and diffusion of carbon dioxide in the Glowworm Cave, New Zealand. In: Cave and Karst Management in Australasia XIII, Mt Gambier, South Australia: 84-89.

de Freitas, C.R., Littlejohn, R.N., 1987. Cave climate: assessment of heat and moisture exchange. Journal of Climatology, 7(6), 553-569.

https://doi.org/10.1002/joc.3370070604

de Freitas, C.R., Littlejohn, R.N., Clarkson, T.S., Kristament, I.S., 1982. Cave climate: assessment of airflow and ventilation. International Journal of Climatology, 2(4), 383-397.

https://doi.org/10.1002/joc.3370020408

de Freitas, C.R., Schmekal, A., 2003. Condensation as a microclimate process: Measurement, numerical simulation and prediction in the Glowworm Cave, New Zealand. International Journal of Climatology, 23(5), 557-575.

https://doi.org/10.1002/joc.898

Hall, C.M., 2013. Glow-worm tourism in Australia and New Zealand. In: Lemelin, R.H. (Ed.), The management of insects in recreation and tourism. Cambridge University Press, Cambridge, p. 217-232.

Hendy, C.H., 1971. The isotopic geochemistry of speleothems - I. The calculation of the effects of different modes of formation on the isotopic composition of speleothems and their applicability as palaeoclimatic indicators. Geochimica et Cosmochimica Acta, 35(8), 801-824. https://doi.org/10.1016/0016-7037(71)90127-X

Kermode, L., 1977. Some aspects of the influence of tourists on the microclimate of Waitomo Cave. New Zealand Geological Survey, Otara, New Zealand, 76 p.

Kermode, L., 1979. Cave corrosion by tourists. In: Cave Management in Australasia III. Proceedings of the 
3rd Australasian conference on cave tourism and management, South Australia: 97-104.

Kukuljan, L., Gabrovšek, F., Covington, M.D., 2021a. The relative importance of wind-driven and chimney effect cave ventilation: Observations in Postojna Cave (Slovenia). International Journal of Speleology, 50(3), 275-288.

https://doi.org/10.5038/1827-806X.50.3.2392

Kukuljan, L., Gabrovšek, F., Covington, M.D., Johnston, V.E., 2021b. $\mathrm{CO}_{2}$ dynamics and heterogeneity in a cave atmosphere: role of ventilation patterns and airflow pathways. Theoretical and Applied Climatology, 146, 91-109.

http://doi.org/10.1007/s00704-021-03722-w

McCabe, B., 1977. The geochemistry of ground water solutions entering limestone caverns. Unpublished MSc thesis, University of Waikato, $145 \mathrm{p}$.

Merritt, D.J., Patterson, R., 2017. Environmental influences on the bioluminescence display of the glowworm, Arachnocampa flava (Diptera: Keroplatidae). Austral Entomology, 57, 107-117. https://doi.org/10.1111/aen.12274

Meyer-Rochow, V.B., 2007. Glowworms: a review of Arachnocampa spp. and kin. Luminescence, 22(3), 251-265. https://doi.org/10.1002/bio.955

Mlakar, P., Grašič, B., Božnar, M.Z., Popović, D., Gabrovšek, F., 2020. Information system for scientific study of the micrometeorology of karst caves-Case of Postojnska jama cave, Slovenija. Acta Carsologica, 49(2-3), 297-310.

https://doi.org/10.3986/ac.v49i2-3.7540

Moulds, T., Anderson, J., Anderson, R., Nykiel, P., 2013. Preliminary Survey of Cave Fauna in the Gunung Mulu World Heritage Area, Sarawak, Malaysia. Unpublished Report to Sarawak Forestry, 89 p.

Novas, N., Gázquez, J.A., MacLennan, J., García, R.M., Fernández-Ros, M., Manzano-Agugliaro, F., 2017. A real-time underground environment monitoring system for sustainable tourism of caves. Journal of Cleaner Production, 142, 2707-2721.

https://doi.org/10.1016/j.jclepro.2016.11.005

Piorkowski, D., Blackledge, T.A., Liao, C.-P., Doran, N.E., Wu, C.-L., Blamires, S.J., Tso, I.-M., 2018. Humiditydependent mechanical and adhesive properties of Arachnocampa tasmaniensis capture threads. Journal of Zoology, 305(4), 256-266.

https://doi.org/10.1111/jzo.12562

Prelovšek, M., Šebela, S., Turk, J., 2018. Carbon dioxide in Postojna Cave (Slovenia): spatial distribution, seasonal dynamics and evaluation of plausible sources and sinks. Environmental Earth Sciences, 77(7), 289. https://10.1007/s12665-018-7459-6

Pugsley, C.W., 1984. Ecology of the New Zealand Glowworm, Arachnocampa luminosa (Diptera: Keroplatidae), in the Glowworm Cave, Waitomo. Journal of the Royal Society of New Zealand, 14(4), 387-407. https://doi.org/10.1080/03036758.1984.10421739

Richards, A.M., 1960. Observations on the New Zealand glow-worm Arachnocampa luminosa (Skuse) 1890. Transactions of the Royal Society of New Zealand, 88(3), 559-574.

Šebela, S., Prelovšek, M., Turk, J., 2013. Impact of peak period visits on the Postojna Cave (Slovenia) microclimate. Theoretical and Applied Climatology, 111(1), 51-64. https://10.1007/s00704-012-0644-8

Šebela, S., Turk, J., 2014. Natural and anthropogenic influences on the year-round temperature dynamics of air and water in Postojna show cave, Slovenia. Tourism Management, 40, 233-243.

https://doi.org/10.1016/j.tourman.2013.06.011

Smith, A.C., Wynn, P.M., 2013. Natural and anthropogenic factors which influence aerosol distribution in Ingleborough Show Cave, UK. International Journal of Speleology, 42(1), 49-56.

http://dx.doi.org/10.5038/1827-806X.42.1.6

The Engineering Toolbox. https://www.engineeringtoolbox. com [accessed: 22 October, 2021].

von Byern, J., Chandler, P., Merritt, D., Adlassnig, W., Stringer, I., Meyer-Rochow, V.B., Kovalev, A., Dorrer, V., Dimartino, S., Marchetti-Deschmann, M., Gorb, S., 2019. Biomechanical properties of fishing lines of the glowworm Arachnocampa luminosa (Diptera; Keroplatidae). Scientific Reports, 9(1), 3082. https://doi.org/10.1038/s41598-019-39098-1

von Byern, J., Dorrer, V., Merritt, D.J., Chandler, P., Stringer, I., Marchetti-Deschmann, M., McNaughton, A., Cyran, N., Thiel, K., Noeske, M., 2016. Characterization of the fishing lines in Titiwai (= Arachnocampa luminosa Skuse, 1890) from New Zealand and Australia. Plos One, 11(12), e0162687.

https://doi.org/10.1371/journal.pone.0162687

Walker, A.A., Weisman, S., Trueman, H.E., Merritt, D.J., Sutherland, T.D., 2015. The other prey-capture silk: Fibres made by glow-worms (Diptera: Keroplatidae) comprise cross- $\beta$-sheet crystallites in an abundant amorphous fraction. Comparative Biochemistry and Physiology Part B: Biochemistry and Molecular Biology, 187, 78-84. https://doi.org/10.1016/j.cbpb.2015.05.008

White, J.H., Dominguez-Villar, D., Hartland, A., 2021. Condensation corrosion alters the oxygen and carbon isotope ratios of speleothem and limestone surfaces. Results in Geochemistry, 2, 100008. https://doi.org/10.1016/j.ringeo.2021.100008

Williams, D.R., 1981. Climate and ecology studies and management at Waitomo Caves. In: Proceedings of the 4th Australian Conference on Cave Tourism and Management, Yallingup, Western Australia.

Willis, R.E., White, C.R., Merritt, D.J., 2010. Using light as a lure is an efficient predatory strategy in Arachnocampa flava, an Australian glowworm. Journal of Comparative Physiology B, 181, 477-486. https://doi.org/10.1007/s00360-010-0533-3 